\title{
Hatchability Traits of Domyati Duck Eggs and Subsequent growth Performance of Ducklings As Affected By Pre-Incubation in Ovo Injection with L-Carnitine \\ Ghonim, A.I.A. \\ Anim. Prod. Res. Institute, Agric. Res. Center, Ministry of Agric. Dokki, Giza.
}

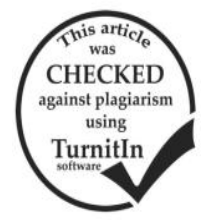

\section{ABSTRACT}

The main objective of the experiment is to study the effects of pre-incubation in ovo injection with different levels of Lcarnitine (L-Car) on hatchability traits of Domyati duck eggs and subsequent growth performance, carcass traits, and some blood plasma constituents of ducklings. A total of 504 eggs were obtained from Domyati duck flock with an average weight $68 \mathrm{gm}$. Before incubation, eggs were randomly divided into six main groups each of 84 eggs in three replicates ( 28 eggs each). The $1^{\text {st }}$ group was used as a negative control (C) without injection.The $2^{\text {nd }}$ group (S)was used as a positive control injected with $0.1 \mathrm{ml}$ saline solution (solvent). The $3^{\text {rd }}, 4^{\text {th }}, 5^{\text {th }}$, and $6^{\text {th }}$ groups were injected with $0.1 \mathrm{ml}$ saline solution contains: $2,4,6$ or 8 mg L-Car respectively. Hatchability, early (at 10 days of incubation), late (at the end of incubation) embryonic mortality and culled ducklings percentages were calculated based on the number of the fertile eggs. A total of 180 hatched ducklings belonging to the same six experimental treatment groups were divided into six groups,(of 30ducklings in three replicate, 10 ducklings each). The Live body weight, body weight gain, feed consumption, feed conversion ratio and performance index were determined. The results indicated that, injection with 6 or $8 \mathrm{mg}$ L-Car had significantly $(\mathrm{P} \leq 0.01)$ increased hatchability $(\%)$ compared with the other treatment groups. Also, early and late embryonic mortality were significantly $(\mathrm{P} \leq 0.05)$ decreased by in ovo injection with $\mathrm{L}-$ Car at doses 6 or $8 \mathrm{mg}$ and insignificantly decreased culled ducklings. A significant $(\mathrm{P} \leq 0.01)$ improvement of live body weight from hatch up to the end of experimental period(1-84 days of age) was observed. The highest values were recorded by in ovo injection with L-Car at doses 6, 8, 4, and $2 \mathrm{mg}$ respectively compared to the control groups. Ducklings hatched from eggs injected with L-Car $(8$ or $6 \mathrm{mg})$ had significantly $(\mathrm{P} \leq 0.01)$ improved body weight gain at the period from $1-28$ day and the whole experimental period from 1-84 day of age. Significant improvement of feed conversion ratio and performance index was observed as a result of in ovo injection with L-Car. The better values were recorded by $6,8,4$ and $2 \mathrm{mg}$ respectively compared to the control groups. The pre incubation in ovo injection with L-Car into Domyati duck eggs at doses of 2, 4, 6 and 8 mg, resulted in significant increase $(\mathrm{P} \leq 0.05)$ in the relative weight of empty carcass, major and minor pectrolis, Thigh muscle and liver, while, the breast skin with its subc. fat, Thigh skin with its subc. fat and abdominal fat (\%) were significantly decreased as compared to the control groups. Plasma triglycerides, thyroxine, $\left(\mathrm{T}_{4}\right)$ and triiodothyronine $\left(\mathrm{T}_{3}\right)$ levels were significantly lower (for triglycerides) and higher for $\mathrm{T}_{4}$ and $\mathrm{T}_{3}$ hormones in the L-Car treatments compared with the control groups. Blood plasma level of MDA was significantly lower of ducks that hatched from L-Car injected eggs, especially those injected with $6 \mathrm{or} 8 \mathrm{mg} / \mathrm{egg}$. It is concluded that, the pre-incubation in ovo injection with 6 or $8 \mathrm{mg}$ L-carnitine could be used as a tool for improving the hatchability traits of Domyati duck eggs and growth performance, carcass yield and decrease fat deposition in ducklings carcasses at marketing age. It is suggested to use in ovo injection technique immediately before incubation to reduce the negative impacts (if any) of injection during embryogenesis, and for easy handling of eggs.

Keywords:L-carnitine- in ovo injection- pre-incubation- performance- Carcass- Blood plasma $\mathrm{T}_{3}, \mathrm{~T}_{4}$, MDA- Ducks.

\section{INTRODUCTION}

In ovo feeding of supplemental nutrients may help to overcome the constraint of limited egg nutrients (Foye et al., 2006), and may provide poultry companies with an alternative method to increase hatchability and weight of newly- hatched chick (Ohta et al., 2001). The injection of amino acid mixture into growing embryos in broiler breeder eggs resulted in high body weight at hatch and at $56 \mathrm{~d}$ of age compared with chick from control embryos (Ohta et al., 1999).several studies illustrated that, fortification of fertile eggs with different nutrients, i.e.vitamins, L-carnitine (L-Car) before incubation was reported as promised tool to improve carcass quality by increasing lean to fat percentage and enhance different performance traits of broilers (AbdelFattah et al., 2014 and Mast and Goddeeris, 2000). LCar is anatural vitamin-like amino acid, synthesized within the body from lysine and methionine (Vas and Wanders, 2002). It is used in poultry for multifunctional purposes that include promoting growth, strengthening the immune system and as antioxidant (Adabi et al., 2011). Free radicals responsible for lipid per oxidation are scavenged by L-Car (Rebouche, 1992). In addition to its role as an antioxidant, L-Car transports long chain fatty acids across mitochondrial membranes for $\beta$-oxidation of fatty acids to produce energy. In such situation exogenous supplementation of L-Car could prove advantageous (Buyse et al., 2001).

Recently, Poultry diets have a high percentage of cereal grains that are poorly in essential amino acids needed for better performance, and this plant diets contain low amount of L-Car ( Buyse et al., 2001), therefore, hens fed plant-originated diets, produced eggs contain low concentration of L-Car (Chiodi et al., 1994). It was also documented that chicken embryos have a limited capacity to synthesize L-Car during incubation due to the low activity of the enzyme $\gamma$ butyrobetainehydroxlase, which is essential for L-Car biosynthesis (Borum, 1983; Robouche, 1992). Thus, the injection of L-Car in the fertile egg may decrease embryonic mortality by reducing oxidative stress during the hatch process, thereby increasing hatch rate. Also, L-car used either injected or as dietary supplement was reported to reduce fat deposition and repartitioning in different avian and mammalian species, Arslan et al. (2003);Abdel-Fatth and Shourrap (2012) and Abd ElAzeem, et al. (2014). Salmanzadeh et al.(2012) found that injection of L-Car into eggs of turkey breeder hens at the $6^{\text {th }}$ day of incubation caused significant depression in hatchability percentage, and reported that, reduction in hatchability may be related to the solution injection 
into yolk sac has created a cavity that may interfere with embryo respiration leading to the embryo death and decreasing hatchability. Al-Murrani (1978) suggested that differences in protein content of eggs at days o and 7 of incubation could affect the growth of embryos. AlDaraji et al. (2012) reported that, the in ovo injection of L- arginine at 0 day of incubation could be used as an efficient tool to improve the productive performance of Japanese quail. To avoid the problem of injection site (amnion or yolk sac) which lead to embryos death and decrease hatchability, thus, this study aimed to investigate the effect of in ovo injection with different level of L- Car at pre- incubation on hatchability traits of Domyati duck eggs and subsequent growth performance, crcass traits, and some blood plasma constituents of growing Domyati ducklings.

\section{MATERIALS AND METHODS}

This study was carried out at El - Serw Water Fowl Research Station, Animal Production Research Institute, Agriculture Research Center, Ministry of Agriculture, Egypt. During winter season.

\section{In ovo injection and Hatching:}

A total of 450 eggs with an average weight of $68 \mathrm{~g}$ were obtained from a Domyati duck breeder flock. At pre incubation, this eggs were randomly divided in six groups each of 75 eggs; in three replicates each of 25 eggs was punctured in the large end to make a hole by hard and thin stylus and this area was disinfected by using ethyl alcohol and the tested material was injected in the air cell by using graded insulin syringe $(1 \mathrm{ml})$, then, sealed using nontoxic glue. L-Car hydrochloride $98 \%$ purity was used. The in-ovo injection of the six experimental groups was designed as follows:

1. The first group (C) was negative control.

2. The second group (S) was sham-injected control (injected with $0.1 \mathrm{ml}$ saline solution as a solvent).

3. The third, fourth, fifth and sixth groups were injected with $0.1 \mathrm{ml}$ of saline solution containing $2,4,6$ and 8 mg L-Car respectively.

All eggs were incubated at $37.5{ }^{\circ} \mathrm{C}$ and $65 \%$ relative humidity $(\mathrm{RH})$ in an automatic incubator. At day 25 of incubation all eggs were transferred to the hatcher to complete the hatching process for 3 days at $37.0^{\circ} \mathrm{C}$ and $75 \% \mathrm{RH}$.

Birds and management: A total of 180 hatched ducklings belonging to the same six experimental treatment groups were weighed and distributed into six groups, ( each 30 ducklings in three replicate each of 10 ducklings).

Ducklings were reared under similar environmental and managerial conditions. They were fed on commercial starter (1-42 d) and Finisher (4384d) mash diets. The composition and calculated analysis of the experimental diets are shown in Table 1.

\section{Data collection:}

1-Hatchability traits: : At the $10^{\text {th }}$ day of incubation, the eggs of all treatments were light candled and clear eggs ( 9 eggs per each group) or those containing early dead embryos were recorded and removed. After hatching, eggs that failed to hatch were broken out to determine the percentage of late embryonic mortality. Hatchability, culled ducklings, early and late embryonic mortality percentages were calculated based on the number of the fertile eggs ( 75 fertile eggs per each group).

2-Growth performance parameters: Live body weight (LBW) of ducklings were recorded at hatch, 28,56 and 84 day of age. The body weight gain (BWG), feed consumption (FC), feed conversion ratio (FCR) and performance index (PI) were calculated through the periods from 1-28, 29-56, 5784 and 1-84 day of age.

Performance index(PI) was calculated as live body weight $(\mathrm{Kg}) /$ feed conversion ratio x 100 , according to North, 1984.

3-Slaughter test: At the end of experimental period (84 day of age), three ducklings from each treatment group were randomly chosen and slaughtered after 12 hours fasting. Feather were removed after dipping in hot water. Legs and head were removed, thereafter, carcass as was eviscerated. Abdominal fat (fat pad, gizzard and intestinal fat)was dissected and weighed; Edible organs included heart; empty gizzard and liver were weighed and calculated as a relative weight of empty carcass. Relative weight of Empty Carcass (without head and legs)was calculated on the basis of live body weight. Breast and Thigh skin with subcutaneous(subc.) fat were dissected, weighed and expressed as a percentage of empty carcass. Major and minor pectoralis (breast muscle) were dissected and weighed, then, expressed as a percentage of empty carcass. All edible parts were calculated as a percentage of empty carcass.

Table1: Composition and calculated analysis of the basal diets.

\begin{tabular}{lcc}
\hline Ingredients \% & Starter & Grower \\
\hline Yellow Corn & 61.70 & 71.00 \\
Soybean meal (44 \%) & 34.55 & 17.60 \\
Wheat bran & 0.00 & 7.60 \\
Di-calcium phosphate & 1.60 & 1.60 \\
Limestone & 1.45 & 1.50 \\
Vit. \& Min. premix & 0.30 & 0.30 \\
NaCl & 0.30 & 0.35 \\
DL. Methionine & 0.10 & 0.05 \\
Total & 100.0 & 100 \\
Calculated Analysis & & \\
Crude protein \% & 20.01 & 15.02 \\
ME ( Kcal / kg ) & 2841 & 2870 \\
Ether extract . \% & 2.86 & 3.07 \\
Crude fiber \% & 3.94 & 3.63 \\
Calcium (\%) & 1.04 & 1.00 \\
Av. phosphorus (\%) & 0.44 & 0.42 \\
Lysine \% & 1.17 & 0.70 \\
Methionine \% & 0.45 & 0.30 \\
Methio + Cyst \% & 0.78 & 0.58 \\
Sodium & 0.13 & 0.16 \\
\hline 1 & &
\end{tabular}

1- $\quad$ Each $3 \mathrm{~kg}$ of the Vit and Min. premix manufactured by AgriVit Company, Egypt contains: Vitamin A 10 MIU, Vit. D 2 MIU, Vit E $10 \mathrm{~g}$, Vit. K 2 g, Thiamin $1 \mathrm{~g}$, Riboflavin $5 \mathrm{~g}$, Pyridoxine $1.5 \mathrm{~g}$, Niacin $30 \mathrm{~g}$, Vit. B12 $10 \mathrm{mg}$, Pantothenic acid $10 \mathrm{~g}$, Folic acid $1.5 \mathrm{~g}$, Biotin $50 \mathrm{mg}$, Choline chloride $250 \mathrm{~g}$, Manganese $60 \mathrm{~g}$, Zinc $50 \mathrm{~g}$, Iron $30 \mathrm{~g}$, Copper $10 \mathrm{~g}$, Iodine 1g, Selenium 0.10 g, Cobalt 0.10 g. and carrier $\mathrm{CaCO}$ to $3000 \mathrm{~g}$..

2- According to Feed Composition Tables for animal and poultry feedstuffs used in Egypt (2001). 
4-Plasma biochemical analysis: During slaughter test, individual blood samples were withdrawn from three birds within each treatment in heparinized test tubes; then centrifuged at $3500 \mathrm{rpm}$ for 15 minutes to get blood plasma. Plasma samples were stored at -20 ${ }^{\circ} \mathrm{C}$ until analysis to determine total protein (Gornal et al., 1949) and albumin (Doumas, et al., 1971) by using commercial kits. However, globulin was obtained by subtraction of plasma albumin from total protein. Triglycerides, (Fassati, P. and L. Prencipe, 1982), cholesterol (Allain et al.,, 1974), High density lipoprotein ( HDL) -cholesterol (Lopez-Virella., 1977) and Low density lipoprotein ( LDL) - cholesterol (Friedewald, 1972),were measured by available commercial kits. The radioimmunoassay (RIA) method was used for the determination of triiodothyronine (T3) and thyroxine (T4) using commercial kits according to Britton et al. (1975); Malondialdhyde (MDA) according to Mihara and Uohiyama,( 1978).

5- Statistical analysis: Data were subjected to one way analysis of variance using general linear model (GLM) procedure of SAS program (SAS, 2004) based on the following model:

where,

$$
\text { Yij }=\mu+T+e i j
$$

Yij = An observation, $\mu=$ Overall mean,

$\mathrm{Ti}=$ Effect of treatment $(1,2, \ldots ., 6)$, and eij $=$

Random error. All percentage data were subjected to arcsine transformation of the square root before statistically reanalyzed however, the actual percentage means are presented. Significant differences among treatments means were tested by Duncan's multiple range test (Duncan, 1955) at a probability level of 0.05 $(\mathrm{p} \leq 0.05)$.

\section{RESULTS AND DISCUSSION}

\section{1-Hatchability traits:}

Results concerning the effects of pre- incubation, in ovo injection of L-Car on hatchability traits of Domyati duck eggs are presented in Table 2.Data indicated that, L-Car injection treatments $(6,8, \mathrm{mg})$ significantly increased $(\mathrm{P} \leq 0.01)$ hatchability percentage, while, significantly decreased $(\mathrm{P} \leq 0.02)$ of early and late embryonic $(\mathrm{P} \leq 0.01)$ mortality in comparison with control groups. On the other hand, culled ducklings were insignificantly decreased for the groups injected with 6 or $8 \mathrm{mg}$ L-Car. The highest values of hatchability (\%) were detected by in ovo L-Car injection with 6 or 8 $\mathrm{mg}$, which the lowest values for early and late embryonic mortality. The improvement of hatchability (\%) and decreasing of early and late embryonic mortality may be due to the role of L-Car in the increase of ATP release from fatty acid catabolism, which in turn be used by chick to facilitate hatching. Furthermore, it may work as antioxidant by scavenging free radicals, hence, reduces the incidence of late dead embryos(Zahi et al., 2008). The significant increase in hatchability may be due also to improvement of antioxidant status, as oxidative metabolism increased in the last few days before hatch. This normal respiration related to embryo growth results in production of free radicals, which can cause tissue damage through lipid peroxidation. Then, the protective effect of L-Car as antioxidant is apparent during the highly oxidative state at pipping and hatching. This was also protect chicks during the first few days after hatch (Surai, 1999). Our results are in close agreement with those reported by Abd El-Azeem e al., 2014 and Abdel- Fattah and shourrap, 2012.However, Dooley et al., 2011; Zahi et al., 2008a; Keralapurath et al., 2010 and Shafey et al., 2010, found no effect of L-Car on percentage of hatchability. Also, Salmanzadeh et al., 2012, reported that, in ovo injection of L-Car $(10,20$ or $30 \mathrm{mg})$ on day 6 of incubation of turkey breeder eggs caused significant decrease of hatchability.

Table 2: Effect of in ovo injection by L-Carnitine ( $\mathrm{L}$ Car) on hatchability traits of Domyati duck eggs.

\begin{tabular}{lcccccccc}
\hline \multirow{2}{*}{ Traits(\%) } & \multicolumn{9}{c}{ Treatments } & \multirow{2}{*}{ LEM Sig. } \\
& $\mathbf{C}$ & $\mathbf{S}$ & $\mathbf{2 . 0}$ & $\mathbf{4 . 0}$ & $\mathbf{6 . 0}$ & $\mathbf{8 . 0}$ & & \\
\hline Hatchability & $69.3^{\mathrm{c}}$ & $69.3^{\mathrm{c}}$ & $70.7^{\mathrm{cb}}$ & $72.0^{\mathrm{b}}$ & $76.0^{\mathrm{a}}$ & $76.0^{\mathrm{a}}$ & 0.58 & $* *$ \\
E.E. M. & $9.3^{\mathrm{a}}$ & $9.3^{\mathrm{a}}$ & $8.0^{\mathrm{ab}}$ & $8.0^{\mathrm{ab}}$ & $6.7^{\mathrm{b}}$ & $6.7^{\mathrm{b}}$ & 0.58 & $*$ \\
L. E. M. & $18.7^{\mathrm{a}}$ & $18.7^{\mathrm{a}}$ & $18.7^{\mathrm{a}}$ & $17.3^{\mathrm{ab}}$ & $16.0^{\mathrm{b}}$ & $16.0^{\mathrm{b}}$ & 0.58 & $* *$ \\
Culled & 2.7 & 2.7 & 2.7 & 2.7 & 1.3 & 1.3 & 0.47 & NS \\
ducklings & 2.7 & 2.7 & & & & & &
\end{tabular}

E.E.M\&L.E.M.=early and late embryonic mortality;SEM= pooled standard error mean; Sig.= significant; $N S=$ non- significant.

a,b,c...means within row with different superscripts are significantly different. $*=(\mathrm{P} \leq 0.05) ; * *=\mathrm{P} \leq 0.01$.

$\mathrm{C}=$ Negative control; $\mathrm{S}=$ Positive control.

\section{2-Productive performance:}

Results presented in Table 3, showed significant effects of the pre-incubation injection of Domyati duck eggs with L-car on post-hatch growth performance of ducklings.

Live body weight (LBW): It is clearly noticed from the present results that, pre-incubation in ovo injection with L-Car improved significantly $(\mathrm{P} \leq 0.01) \quad$ LBW of Domyati ducklings at different ages from hatch to 84 day of age as compared to control groups. The best values of LBW were recorded by the group injected with $6 \mathrm{mg}$ L-car followed by groups injected with 8 or $4 \mathrm{mg}$ L-Car throughout the experimental period,(from one up to 84 day of age). This may be a consequence of the high hatching weight of this group compared with the other groups. Moreover, the increased LBW at different ages is due mainly to the increased myogenesis during incubation as a result of L-Car injection. Also, an increase in efficiency of fatty acids oxidation which subsequently led to an improved utilization of dietary nitrogen thereafter. Our results are in close agreement with Rabie et al. 2015, onCobb-500 broiler breeder and Abed El-Azeem et al. 2014 on Cobb-500 broiler breeder.However, Zahi et al. (2008b) reported that, in ovo injection of L-Car into fertile eggs at 17 or $18 \mathrm{~d}$ of incubation did not affect LBW. Moreover, Keralapurath, (2010) stated that, no significant effects of L-Car doses $(0.5,2.0,8 \mathrm{mg})$ injected in fertilized eggs at the $18^{\text {th }}$ day of incubation on growth performance of white Leghorn. These differences are due mainly to different magnitudes of time and dose of L-Car and also to the bird species, since in the present study Domyati ducks were used. 
Ghonim, A.I.A.

Table 3: Effect of in ovo injection by $L$-carnitine(L-Car) on live body weight body weight gain, feed consumption, feed conversion ratio and performance index of Domyati ducklings in different growing periods.

\begin{tabular}{|c|c|c|c|c|c|c|c|c|}
\hline \multirow{3}{*}{ Age (day) } & \multicolumn{6}{|c|}{ Treatments } & \multirow{3}{*}{ SEM } & \multirow{3}{*}{ Sig. } \\
\hline & \multirow{2}{*}{$\mathbf{C}$} & \multirow{2}{*}{$\mathbf{S}$} & \multicolumn{4}{|c|}{ L-Car doses $(\mathrm{mg})$} & & \\
\hline & & & 2.0 & 4.0 & 6.0 & 8.0 & & \\
\hline \multicolumn{9}{|c|}{ Live body weight(g/ duckling) at } \\
\hline Hatch & $37.3^{\mathrm{c}}$ & $37.7^{\mathrm{c}}$ & $40.7^{\mathrm{b}}$ & $41.3 \mathrm{a}^{\mathrm{b}}$ & $43.0^{\mathrm{a}}$ & $43.3^{\mathrm{a}}$ & 0.7 & $* *$ \\
\hline 28 day & $943.3^{\mathrm{c}}$ & $941.7^{\mathrm{c}}$ & $1015.3^{\mathrm{b}}$ & $1005.0^{\mathrm{b}}$ & $1073.3^{\mathrm{a}}$ & $1056.7^{\mathrm{a}}$ & 11.6 & $* *$ \\
\hline 56 day & $1836.7^{\mathrm{c}}$ & $1833.3^{\mathrm{c}}$ & $1908.3^{\mathrm{b}}$ & $1906.7^{\mathrm{b}}$ & $1983.7^{\mathrm{a}}$ & $1963.3 \mathrm{a}^{\mathrm{b}}$ & 19.5 & $* *$ \\
\hline 84 day & $2216.7^{\mathrm{dc}}$ & $2207.7^{\mathrm{d}}$ & $2283.0^{\mathrm{bc}}$ & $2336.7^{\mathrm{ab}}$ & $2402.3^{\mathrm{a}}$ & $2380.0^{\mathrm{a}}$ & 23.3 & $* *$ \\
\hline \multicolumn{9}{|c|}{ Body weight gain (g/duckling/28 day) } \\
\hline $1-28$ & $906.0^{c}$ & $903.7^{\mathrm{c}}$ & $974.7^{\mathrm{b}}$ & $963.7^{\mathrm{b}}$ & $1030.3^{\mathrm{a}}$ & $1013.3^{\mathrm{a}}$ & 11.8 & $* *$ \\
\hline $29-56$ & 893.0 & 891.7 & 893.0 & 901.7 & 910.3 & 906.7 & 16.1 & NS \\
\hline $57-84$ & 380.0 & 374.3 & 374.7 & 430.0 & 419.7 & 416.7 & 16.5 & NS \\
\hline $1-84$ & $2179.3^{\mathrm{c}}$ & $2170.0^{\mathrm{c}}$ & $2242.3^{\mathrm{bc}}$ & $2295.3^{\mathrm{ab}}$ & $2360.3^{\mathrm{a}}$ & $2336.7^{\mathrm{a}}$ & 23.2 & $* *$ \\
\hline \multicolumn{9}{|c|}{ Feed consumption (g/duckling/28day) } \\
\hline $1-28$ & $2285.0^{\mathrm{a}}$ & $2275.0^{\mathrm{a}}$ & $2275.0^{\mathrm{a}}$ & $2281.7^{\mathrm{a}}$ & $2246.7^{b}$ & $2240.0^{\mathrm{b}}$ & 7.1 & $* *$ \\
\hline $29-56$ & 2623.3 & 2600.0 & 2583.3 & 2563.3 & 2543.3 & 2580.0 & 32.0 & NS \\
\hline $57-84$ & 3100.0 & 3143.3 & 2995.0 & 3170.0 & 3059.3 & 3050.0 & 54.0 & NS \\
\hline $1-84$ & 8008.3 & 8018.3 & 7853.3 & 8015.0 & 7849.3 & 7870.0 & 66.8 & NS \\
\hline \multicolumn{9}{|c|}{ Feed conversion ratio (g. feed/g.gain) } \\
\hline $1-28$ & $2.6^{\mathrm{a}}$ & $2.5^{\mathrm{a}}$ & $2.3^{\mathrm{b}}$ & $2.4^{\mathrm{b}}$ & $2.2^{\mathrm{c}}$ & $2.2^{\mathrm{c}}$ & 0.4 & $* *$ \\
\hline $29-56$ & 2.9 & 3.0 & 2.9 & 2.8 & 2.8 & 2.8 & 0.1 & NS \\
\hline $57-84$ & $8.2^{\mathrm{a}}$ & $8.4^{\mathrm{a}}$ & $8.0^{\mathrm{ab}}$ & $7.1^{\mathrm{c}}$ & $7.3^{\mathrm{c}}$ & $7.4 \mathrm{cb}$ & 0.22 & $* *$ \\
\hline $1-84$ & $3.7^{\mathrm{a}}$ & $3.7^{\mathrm{a}}$ & $3.5^{\mathrm{b}}$ & $3.5^{\mathrm{b}}$ & $3.3^{\mathrm{c}}$ & $3.4^{\mathrm{c}}$ & 0.03 & $* *$ \\
\hline \multicolumn{9}{|c|}{ Performance index (LBW, kg / FCR x 100$)$} \\
\hline $1-28$ & $36.8^{\mathrm{c}}$ & $37.2^{\mathrm{c}}$ & $43.5^{\mathrm{b}}$ & $41.9^{\mathrm{b}}$ & $48.1^{\mathrm{a}}$ & $48.0^{\mathrm{a}}$ & 0.9 & ** \\
\hline $29-56$ & $62.7^{\mathrm{b}}$ & $61.9^{\mathrm{b}}$ & $66.5^{\mathrm{ab}}$ & $67.4 \mathrm{a}^{\mathrm{b}}$ & $71.0^{\mathrm{a}}$ & $69.3^{\mathrm{a}}$ & 1.7 & $*$ \\
\hline $57-84$ & $277^{1 \mathrm{~b}}$ & $26.3^{\mathrm{b}}$ & $28.6^{\mathrm{b}}$ & $33.1^{\mathrm{a}}$ & $33.6^{\mathrm{a}}$ & $32.4^{\mathrm{a}}$ & 1.2 & * \\
\hline $1-84$ & $59.8^{\mathrm{c}}$ & $60.2^{\mathrm{c}}$ & $65.2^{\mathrm{b}}$ & $66.8^{\mathrm{b}}$ & $72.1^{\mathrm{a}}$ & $70.7^{\mathrm{a}}$ & 1.1 & $* *$ \\
\hline
\end{tabular}

a,b,c...means within row with different superscripts are significantly different. $*=(P \leq 0.05) ; * *=(P \leq 0.01)$.

$C=$ Negative control; $S=$ Positive control.

\section{Body weight gain (BWG):}

It is observed that, BWG Table 3, was significantly $(\mathrm{P} \leq 0.01)$ improved for ducklings hatched from eggs injected with L-Car $(2,4,6$ and $8 \mathrm{mg} / \mathrm{egg})$ during period $1-28$ and the whole experimental period 1-84 day of age as compared to control groups (C, S ). The best values were recorded by the groups injected with L-Car doses 6, 8 and $4 \mathrm{mg}$ respectively at the whole period 1-84 day of age. It is noticed that, although, the in ovo L-Car injection treatment groups had no significant effects on BWG at the periods 29-56 and 57-84 day of age, these treatment groups recorded numerically on increase ofBWG as compared to control groups. These results are in agreement with AbdelFattah and shourrap, 2012 on broiler and Salmanzadeh et al.(2012) on turkey. However, Keralapurath et al. (2010), reported that, no significant effects of L-Car injection on weight gain and Zahi et al.(2008)on white leghorn.

Feed consumption (FC):

Feed consumption (FC) of Domyati ducklings hatched from eggs injected with L-Car doses(2, 4, 6 and $8 \mathrm{mg} / \mathrm{egg}$ ) during the different experimental periods (184 day of age) was not significantly affected as compared to control groups, except the period from 128 day of age which was significantly decreased (Table3). It is clear from the results that, in ovo L-Car injection with the doses 6 and $8 \mathrm{mg}$ gave lower values of FC as compared to the other groups at 1-28 day of age. These results are in agreement with those of Rabie et al. (2015)on broiler and Salmanzadeh et al., on turkey breeder strain.

\section{Feed conversion ratio (FCR):}

It is clear from the results that in ovo L-Car injection at doses $(2,4,6$, and $8 \mathrm{mg})$ improved significantly $(\mathrm{P} \leq 0.01) \quad$ FCR at different experimental periods except, the period from 29-56 day of age as compared to the control groups Table3. The control groups had significantly $(\mathrm{P} \leq 0.01)$ the poorest values in respect of FCR and those of 6 and $8 \mathrm{mg} \mathrm{L}-\mathrm{Car}$ injected groups which were the best, However, those of 2 and 4 $\mathrm{mg}$ injected groups were intermediates in this respect. This improvement in FCR of ducklings in response to in ovo injection with L-Car may partly explained by the improved final LBW and cumulative BWG, since feed consumption of ducklings was not affected. These results are in close agreement with Rabie et al., 2015; Abed- El-Azeem et al., 2014; Abdel-Fattah and shourrap, 2012; and Salmanzadeh et al., 2012.

\section{Performance index (PI):}

Significant differences were observed in performance index (\%) among the experimental treatment groups due to in ovo L-car injection during all experimental periods (1-84 day ) Table 3. It was observed that, ducklings hatched from eggs injected with L-car by doses $2,4,6$ and $8 \mathrm{mg}$ had improved significantly $(\mathrm{P} \leq 0.01)$ PI during the period from 1-84 day of age. The best PI (\%) values were recorded by the groups received $6 \mathrm{mg}$ followed by 8 , 4and $2 \mathrm{mg}$ L-car doses, respectively. These results may be due to L-car improves body weight gain and feed conversion ratio as 
well as low feed consumption of all treatment groups during the whole experimental period. Also, it may be due to L-car has the ability to improve the use of dietary nitrogen, whether, directly through sparing its precursors (methionine and lysine) for protein biosynthesis and other cellular functions or indirectly by optimizing the balance between essential and nonessential amino acids within the cell (Sarica et al., 2005), which subsequently improve growth performance.

\section{3- Carcass traits:}

Data concerning carcass traits of Domyati ducklings at 84 of age as affected by in ovoL-car injection treatments are presented in Table 4.

Table 4: Effect of in ovo injection by Lcarnitine (L-Car) on carcass traits of domyati ducklings at 84days of age.

\begin{tabular}{|c|c|c|c|c|c|c|c|c|}
\hline \multirow{2}{*}{ Traits, (\%) } & \multirow{2}{*}{$\mathbf{C}$} & \multirow{2}{*}{$\mathbf{S}$} & \multicolumn{4}{|c|}{$\begin{array}{l}\text { Treatments } \\
\text { L-Car doses (mg) }\end{array}$} & \multirow[b]{2}{*}{ SEM } & \multirow[b]{2}{*}{ Sig. } \\
\hline & & & 2.0 & 4.0 & 6.0 & 8.0 & & \\
\hline Empty carcass & $67.2^{b}$ & $67.0^{\mathrm{b}}$ & $67.2^{\mathrm{b}}$ & $71.3 \mathrm{a}$ & $71.9^{\mathrm{a}}$ & $71.4^{\mathrm{a}}$ & 0.89 & $* *$ \\
\hline Major pectoralis & $12.4^{\mathrm{cb}}$ & $12.3^{\mathrm{c}}$ & $13.0^{\mathrm{cb}}$ & $13.2^{\mathrm{b}}$ & $14.0^{\mathrm{a}}$ & $14.0^{\mathrm{a}}$ & 0.24 & $* *$ \\
\hline Minor pectoralis & $1.7^{\mathrm{b}}$ & $1.7^{\mathrm{b}}$ & $1.7^{\mathrm{b}}$ & $1.8^{\mathrm{b}}$ & $2.0^{\mathrm{a}}$ & $2.0^{\mathrm{a}}$ & 0.08 & $* *$ \\
\hline Breast skin with subc. Fat & $10.2^{\mathrm{a}}$ & $10.2^{\mathrm{a}}$ & $9.0^{\mathrm{ab}}$ & $8.0^{\mathrm{b}}$ & $8.1^{\mathrm{b}}$ & $8.1^{\mathrm{b}}$ & 0.37 & $* *$ \\
\hline Thigh muscle & $12.3^{b}$ & $12.4^{\mathrm{b}}$ & $14.1^{\mathrm{a}}$ & $13.8^{\mathrm{a}}$ & $14.4^{\mathrm{a}}$ & $13.9^{\mathrm{a}}$ & 0.46 & $* *$ \\
\hline Thigh skin with subc. Fat & $7.1^{\mathrm{a}}$ & $7.0^{\mathrm{a}}$ & $5.8^{\mathrm{b}}$ & $5.0^{\mathrm{cb}}$ & $4.7^{\mathrm{c}}$ & $4.9^{\mathrm{cb}}$ & 0.34 & $* *$ \\
\hline Liver & $2.7^{\mathrm{b}}$ & $2.9^{\mathrm{ab}}$ & $2.7 \mathrm{~b}$ & $2.8^{\mathrm{b}}$ & $3.1^{\mathrm{a}}$ & $2.9^{\mathrm{ab}}$ & 0.08 & $*$ \\
\hline Gizzerd & 3.3 & 3.7 & 3.4 & 3.4 & 3.4 & 3.9 & 0.16 & NS \\
\hline Heart & 1.2 & 1.2 & 1.1 & 1.0 & 1.3 & 1.2 & 0.08 & NS \\
\hline Abdominal fat & $3.7^{\mathrm{a}}$ & $3.7^{\mathrm{a}}$ & $2.9^{\mathrm{b}}$ & $2.9^{\mathrm{b}}$ & $2.4^{\mathrm{b}}$ & $2.5^{\mathrm{b}}$ & 0.22 & $* *$ \\
\hline
\end{tabular}

$\mathrm{SEM}=$ pooled standard error mean; NS: non-significant; $*=\mathbf{P} \leq 0.05 ; * *=\mathbf{P} \leq 0.01$

a,b,c....means within row with different superscripts are significantly different.

$C=$ Negative control; $S=$ Positive control; $S u b c=$ Subcutaneous

The results revealed that, pre incubation in ovo injection with L-car into Domyati duck eggs at doses of 2, 4, 6 and $8 \mathrm{mg}$, resulted in significant increase $(\mathrm{P} \leq 0.05)$ or $(\mathrm{P} \leq 0.01)$ in the relative weight of empty carcass, major and minor pectrolis, thigh muscle and liver, while, the breast skin with its subc. fat, Thigh skin with its subc. fat and abdominal fat (\%) were significantly decreased as compared to the control groups. However, gizzard and heart (\%) were not significantly differed between all treatment groups. The increasing of empty carcass, Major and Minor pectrolis and thigh muscles (\%) may be attributed to the anabolic effect of L-car on muscles building. It is observed that, in ovo L-car injection reduced the abdominal fat and breast; thigh subc. fat compared to the controls, this effect may be related to the action of L-car on energy metabolism as a hypolipidemic drug which induces fatty acids catabolism and splitting ATP energy. It is also possible that in ovo L-Car injection may reduce the number and size of adipocytes during embryogenesis, a phenomena related to fat deposition during the growing period. The proliferation of adipocytes is greatly increased during embryonic development as stated by $\mathrm{Li}$, et al. (2011). These results are in close agreement withRabie et al. (2015)on Cobb-500 broiler breeder; Salmanzadeh et al. (2013), in turkel; Abd El-Azeem et al. (2014), and Abdel-Fattah and Shourrap, (2012,2013), Xu et al.(2003) and Uni et al. (2005).They found that in ovo L-car injection had significant effects on improving carcass yield by increasing lean to fat ratio. However, Keralapurath, (2010) had reported that, in ovo L-car injection of turkey eggs had no effect on all slaughter traits of turkey pullets.

\section{4-Blood plasma constituents:}

The effect of pre incubation injection (in ovo) with different doses of L-Car on some plasma constituents of Domyati ducklings are presented in
Table 5. It is clear from the results that pre-incubation injection of L-Car has no significant effects on plasma total protein, albumin, globulin, A/G ratio; cholesterol, $\mathrm{LDL}$; and $\mathrm{T}_{3} / \mathrm{T}_{4}$ ratio of different treatment groups at 84 day of age. These results reveal that enrichment of ducks eggs with L-Car, immediately before incubation, via in ovo injection has hazard effects on subsequent physiological equilibrium of hatched ducklings from hatch to marketing age $(84 \mathrm{~d})$. However, there are some minor, but insignificant, increases in some plasma constituents of L-Car treatment groups compared with the the control ones, especially for total protein, globulin and HDL levels of the $6 \mathrm{mg} \mathrm{L}-\mathrm{Car}$ treatment. On the other hand, plasma total cholesterol, and LDL were numerically lower for L-Car treatments compared with the control groups.

Results showed also that plasma triglycerides, thyroxine, $\left(\mathrm{T}_{4}\right)$ and triiodothyronine $\left(\mathrm{T}_{3}\right)$ levels were significantly lower (for triglycerides) and higher for $\mathrm{T}_{4}$ and $\mathrm{T}_{3}$ hormones in the L-Car treatments compared with the control groups. The significant decrease in triglycerides and in all plasma lipid fraction (although not significant), could be explained by the fact that LCar plays an important role in body fat regulation and fat deposition. This holds true as Arslan, et al. (2003 and 2006) have reported that L-Car administration, in general, improved fat utilization by distributing excess lipids as intramuscular fat in muscles of ducks and geese, respectively. This support our findings that L-Car injection reduce subcutaneous fat of breast and thigh and abdominal fat percentage along with the significant improvements in carcass, breast and thigh muscles percentages (see Table 4).

It was also observed that thyroid hormones levels were significantly increased in L-Car treatment groups than those of controls (Table 5).It is likely that L-Car injection enhanced both $\mathrm{T}_{4}$ and $\mathrm{T}_{3}$ secretion from thyroid gland either directly via its effect on 
thyroglobulin secretion (the precursor of thyroid hormones) or in directly by a positive feedback mechanism in regulation during the growing period. Of interest, the growth performance of L-Car treated groups was better than the other control which support our view.

Table 5: Effect of in ovo injection of $L$-carnitine (L-Car) on blood plasma constituents of Domyati ducklings at 84day of age.

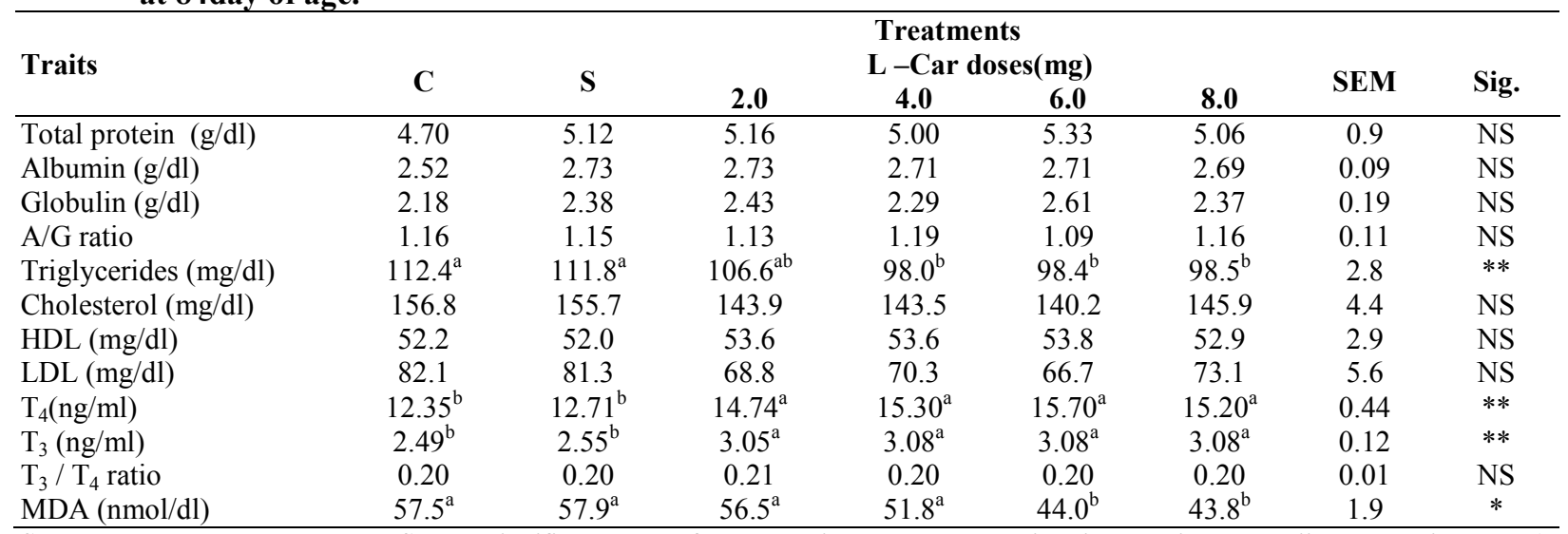

SEM= standard error mean; NS: non-significant; HDL\& $L D L=$ high and low density lipoprotein; $T_{3}=$ triiodothryonine; $M D A=$ Malondialdhyde; T4= thyroxcine; NS= nonsignificant *= significant;

$* *=$ High significant

a,b,.. means withineachrow with different superscripts are significantly different.

$C=$ control Negative; $S=$ Positive control.

Table 5, showed also that MDA level was significantly lower in blood plasma of ducks that hatched from L-Car injected eggs, especially those injected with 6 or $8 \mathrm{mg} / \mathrm{egg}$. In general, during embryonic growth, hatching process and changes to pulmonary respiration causes negative impacts in the antioxidant status of pre hatching ducklings, inducing oxidative stress which causes an increase in MDA concentration and hence, decrease of total antioxidant capacity and endogenous antioxidant enzymes. This was the case for the control treatments, however, L-Car with its antioxidant properties overcome these deleterious effects which was reflected in the low concentration of MDA in a dose-dependent manner. These results are in close agreement with those reported by Surai (1999); Arslan, et al. (2003) and Shafey, et al. (2010).

\section{CONCLUSION}

From the previous results, it could be concluded the pre-incubation in ovo injection with 6 or $8 \mathrm{mg} \mathrm{L}$ Car/egg improved hatchability traits, growth performance, carcass yield and decrease fat deposition in duck carcasses at marketing age. It is suggested to use in ovo injection technique immediately before incubation to reduce the negative impacts (if any) of injection during embryogenesis, and for easy handling of eggs.

\section{REFERENCES}

Abd El- Azeem, A. Nafisa; Sh. Abdo. Marwa; M. Madkour and I. El-Wardany(2014). Physiological and Histological Responses of Broiler Chicks to in ovo Injection with Folic Acid or L-carnitine during Embryogenesis. Glob. Veterin., 13 (4) : 544-551.
Abdel-Fattah, S. A.; E. F. El-Daly and N. G. M. Ali (2014).Growthperformance, immune response, serum metabolites an digestive enzyme activities of japanese quail fed supplemental L-carnitine. Global Ceterinaria, 12 (12):277286.

Abdel-Fattah, S. A. and M. I. Shourrap(2013). Growth muscular proliferation and metabolic hormones expression in broiler chicks as affected by folic acid administration and embryonic thermal conditioning. Egypt. J. Nutri. And feeds. 16 (2): 195-202.

Abdel-Fattah, S. A. and M. I. Shourrap(2012). Physiological effects of in ovo L carnitine and embryonic thermal conditioning on pre and posthatch development of broiler chicks. $3^{\text {rd }}$ Mediterranean Poultry Summit and $6^{\text {th }}$ internationalPoultry Conference, 26-29 Mar. 2012, Alex., Egypt.

Adabi, G. S. H.; R. G. Cooper; N. Ceylan and M. Corduk (2011). L-carnitine and its functional effects in poultry nutrition. World'spoult. Sci. J., 67: 277-296.

Al-Daraji, H. J.; A. A. Al-Mashadani; W. E. AlHassani and H. A. Mirza (2012). Effect of in ovo injection with L-arginine on productive and physiological traits of Japanese quail. S. Afr. J. Sci. Vol.42 n2 pretoria Jan.

Allain, C. C., L. S. Poon; C.S. Chan and W. Richmond (1974). Enzymatic determination of total serum cholesterol. Clin. Chem., 20 (4) : 470-5.

Al-Murrani, W. K. (1978). Maternal effects on embryonic and postembryonic growth in poultry. Br. Poult. Sci. 19: 277-281. 
Arslan, C. (2006). L-carnitine and its use as a feed additive in poultry feeding: A Review. Revue Méd. Vét., 157(3): 134-142.

Arslan, C.; M. Citil and M. Saatc(2003). Effects of L-carnitine administration on growth performance, carcass traits, blood serum parameters and abdominal fatty acid composition of ducks. Arch. Anim. Nutr.( 57): 381-388.

Borum, P.R.( 1983). Carnitine. Annu. Rev. Nutr. ( 3): 233-259.

Britton, K. E; V. C. Quinn; B. L. Brown andR. P. Edkins (1975). Astrategy for thyroid function tests. Brit. Med. J. $111: 350-356$.

Buyse, J.; G.P. Janssens and E. Decuypere (2001). The effect of dietary L-carnitine supplementation on the perfprmance, organ weights and circulating hormone and metabolite concentration of broiler chickens reared under a normal or low temperature schedule. Br. Poult. Sci.( 42):230-241.

Chiodi P. B. Ciani; S. Kentroti; F. Maccari; A. Vernadakis; L. Angelucciand M.T. Ramacci(1994).Carnitine and derivatives in the central nervous system of chick embryo. Int. J. Biochem., 26: 711-720.

Dooley, M., E.D. Peebles, W. Zhai, L. Mejia, C.D. Zumwalt and A. Corzo, (2011). Effects of Lcarnitine via in ovoinjection with or without Lcarnitine feed supplementation on broiler hatchability and posthatch performance. J. Applied Poult. Res., 20: 491-497.

Doumas, B. T.; W. A.Watson and H. G. Biggs (1971). Albumin standerds and measurement of albumin with bromocresol green. Clin. Chim. Acta.( 31): 87-96.

Duncan, D.B. (1955). Multiple range and multiple F tests. Biometrics, 1:1-42.

Fassati, P. andL.Prencipe (1982). Serum triglycerides determination colorimetrically with an enzyme that produces hydrogen peroxide.Clin. chem. (28). 2077.

Feed Composition Tables for Animals and Poultry Feed stuff Used in Egypt (2001). Technical Bulletin No., 1, Central Lab. For Food and feeds (CLFF) Ministry of agric. Res. Cent. Egypt

Foye, O. T. , Z. Uni, and P. R. Ferket(2006). Effect of in ovo feeding egg white protein, betahydroxy-beta-methylbutyrate, and carbohydrates on glycogen status and neonatal growth of turkeys. Poult. Sci.( 85):1185-1192.

Friedewald, W. T. (1972). Estimation of the concentration of low density lipoprotein cholesterol in plasma without use of the preparated ultra centrifuge. Clin. Chem. V. (14): 449-452.

Gornal, A. G.; C. J. Bardawill andM. M. David (1949). Determination of serum proteins by means of the biuret reaction. J. Biol.chem.66177:751.
Keralapurath, M.M.; A. Corzo; R. Pulikanti; W. Zhai and E. D. Peebles(2010). Effects of in ovo injection of L-carnitine on hatchability and subsequent broiler perfprmance and slaughter yield. Poult. Sci., 89 : 1497-1501.

Li, B. C., Y. I. Zhang; X. U. Chen; Q. Q. Shi; Z. T. Gao and G. H. chen (2011).Directional differentiation of chicken embryonic stem cells into osteoblasts, neuron-like cells and adipocyles. AFr. J. Biotechnol., 10: 77727779.

Lopez-Virella, MF; P Stone; S Ellis and J.A. Colwell (1977). Cholesterol determination in high-density lipoproteins separated by three different methods. Clin Chem.( 23):882-884.

Mast, J.; J. Buyse and B. M. Goddeeris (2000). Dietary L-carnitine supplementation increases antigen-specific immunoglobulin $G$ production in broiler chickens. Br. J. Nutr., 83: 161-166.

Mihara, M. and M. Uohiyama (1978). Determenation of malondialdehyde precursors in tissues by thiobarbituric acid test. Anal. Biochem. 86 : 271-278.

North, M.O., (1984). Commercial Chicken Production Manual. $3^{\text {rd }}$ Ed. The AVI publishing Co. Inc. West-port, Connecticut, U.S.A.

Ohta, Y; M.T. Kidd and T. Ishibashi(2001).Embryo growth and amino acid concentration profiles of broiler breeder eggs, embryos, and chicks after in ovo administration of amino acids. Poult. Sci. (80):1430-1436.

Ohta, Y; N. Tsushima; K. Koide ; M.T. Kidd and T. Ishibashi1(999). Effect of amino acid injection in broiler breeder eggs on embryonic growth and hatchability of chicks. Poult. Sci.(78):1493-1498.

Rabie, M.H.; F.S.A. Ismaail and A.A.S. Ahmed( 2015). Effect of in ovoinjection in broiler breeders and post-hatch performance. Asian j. of Anim.and Veter. Advances.,10(12): 875884.

Rebouche, C.J. (1992). Carnitine function and requirements during the life cycle. FASEB J.,6: 3379-3386.

Sarica, S.; M. Corduk and K. Kilinc (2005). The effect of dietary L-carnitine supplementation on growth performance, carcass traits and consumption of edible meat in Japanese quail (Coturnixcoturnix japonica). J. Appl. Poult. Res., 14: 709-715.

SAS Institute. (2004). SAS User's Guide: Statistics. Edition 9.1 . SAS Institute Inc., Cary, NC.

Shafey, T.M.; H.A. Al-Batshan; A.N. AlOwaimerana K.A. Ai-Samawei (2010). Effects of in ovo administration of L-carnitine on hatchability performance,glycogen status and insulin-like growth factor-1 of broiler chickens. Brit. Poult. Sci., 51(1): 122-131. 
Ghonim, A.I.A.

Salmanzadeh, M.; Y. Ebrahimnezhad and H.A. Shahryar(2013). The effect of in ovo injection of L-carnitine on hatching traits, growth perfprmance, and carcass chraracteristics of turkey poults. Bull. Env. Pharmacol. Life. Sci., vol 2(11): 125-128.

Surai, P. F. (1999). Tissue-specific changes in the activities of antioxidant enzymes during the development of the chicken embryo. Brit. Poult. Sci., 40: 397-405.

Uni, Z.; P. R. Ferket; E. Tako and O. Kedar (2005). In ovo feeding improves energy status of lateterm chicken embryo. Poult. Sci., 84: 764-770.
Vaz, F. M. and R. J. Wanders (2002). Carnitine biosynthesis in mammals. Biochem. J. 361: 417-429.

Xu, Z. R.; M.Q. Wang; H.X.Mao; X.A. Zhan and C.H. Hu (2003). Effect of L-carnitine on growth performance, carcass composition, and metabolism of lipids in male broilers. Poult. Sci., 82(3) 408-413.

Zhai, W., S. Neuman, M.A. Latour and P.Y. Hester(2008b).The Effect of in ovo injection of L-carnitine on hatchability of white leghorns. Poult. Sci., 87(3): 569-572.

\section{صفات الفقس وأداء النمو للكتاكيت الناتجة من حقن بيض البط الدمياطى بالكارنيتين قبل التفريخ أيمن إبراهيم عبده غنيم معهد بحوث الانتاج الحيوانيـ- مركز البحوث الزراعيةـوزارة الزراعةـ مصر}

أجريت هذه التجربة لار اسة تأثير حقن بيض البط الدمياطى (سلالة محلية) قبل التفريح بالكارنيتين على صفات الفقس و أداء النمو

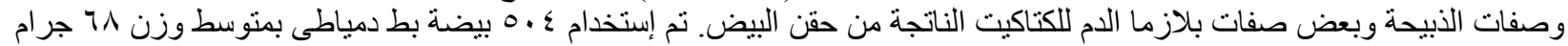

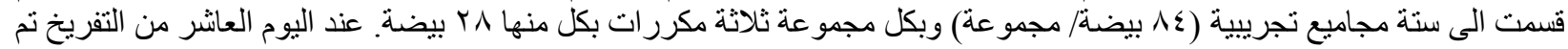

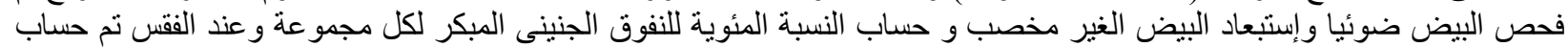

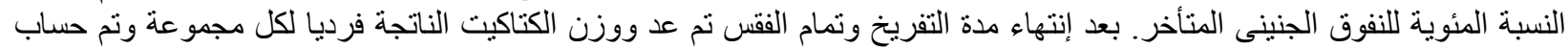

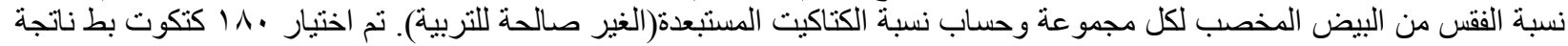

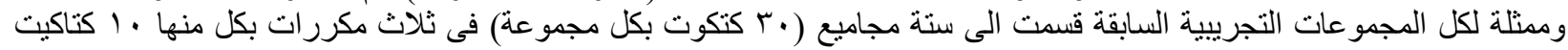

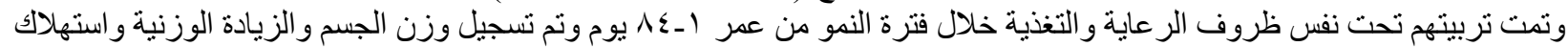

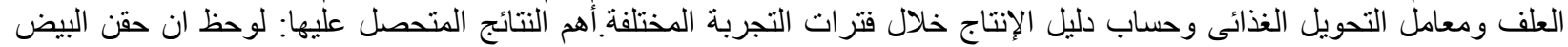

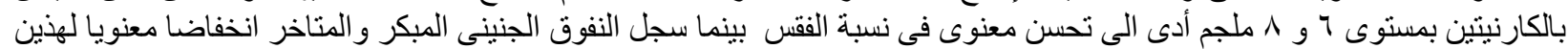

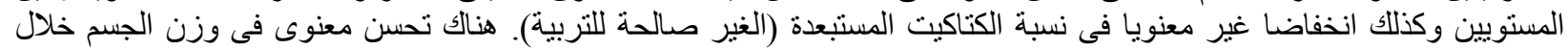

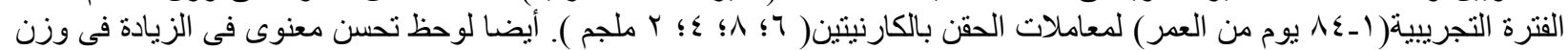

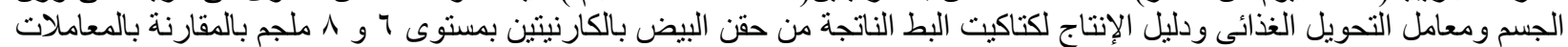

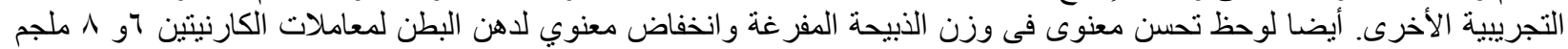

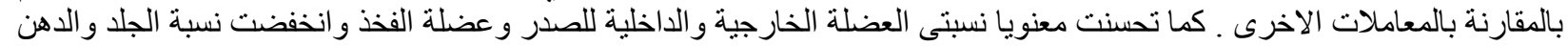

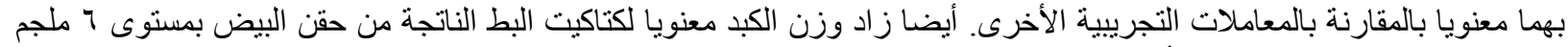

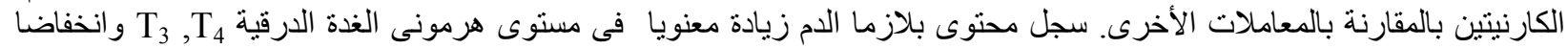

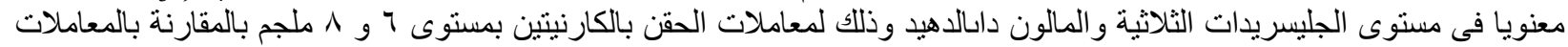

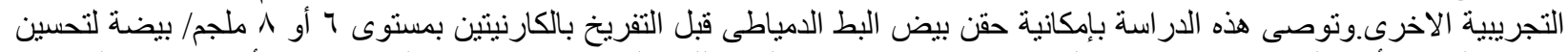

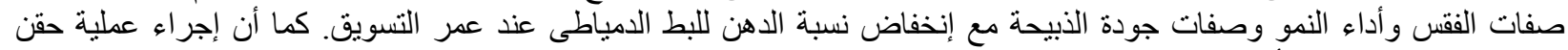

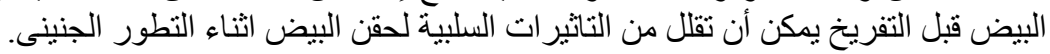

